\title{
ROMANIAN
}

NEUROSURGERY

\author{
Vol. XXXIV | No. 2 June 2020
}

Headache, seizures and loss of consciousness in an elderly male following groin hernia surgery

Amit Agrawal 


\section{Headache, seizures and loss of consciousness in an elderly male following groin hernia surgery}

\section{Amit Agrawal}

\author{
Dr. MCh. Professor of Neurosurgery. Department of Neurosurgery, \\ MM Institute of Medical Sciences \& Research, Mullana (Ambala), \\ INDIA
}

\begin{abstract}
Headache after lumbar puncture is a common occurrence and have a benign course in the majority. In rare cases, it can be a mani-festation of rare but potentially lifethreatening intracranial complications. We discuss a case of 65 years male patient who was operated for left inguinal hernia under spinal anaesthesia, had persistent headache partial response to conservative measures developed one episode of seizures and lapsed into altered sensorium. Imaging findings were suggestive of extensive left frontal-temporoparietal acute SDH with mass effect and midline shift. The hematoma was evacuated and the patient recovered well. Prolonged and persistent post-dural puncture headache complicated by atypical neurological deterioration following spinal anaesthesia should prompt the physician to consider the possibility of intracranial complications and to seek immediate radiological investigations.
\end{abstract}

\section{INTRODUCTION}

Headache after lumbar puncture [post-dural puncture headache $(\mathrm{PDPH})]$ is a common occurrence in most cases after lumbar puncture and most of post-LP headaches are not severe and have a benign course (1-4) but in rare cases PDPH can also be a manifestation of a rare but potentially life-threatening complication such as acute subdural hematoma (SDH). (3, 5-16).

\section{CASE REPORT}

A 65-years old male patient was operated for left inguinal hernia one week back under spinal anaesthesia. He was complaining of persistent headache and with the diagnosis of PDPH he was given analgesics, oral hydration, and bed-rest without much improvement. On 7th day he had multiple episodes of vomiting, one episode of generalized tonicclonic seizures and lapsed into altered sensorium. His general and systemic examination was normal. Per abdomen examination was normal. Bowel sounds were normal. Neurologically he was in altered

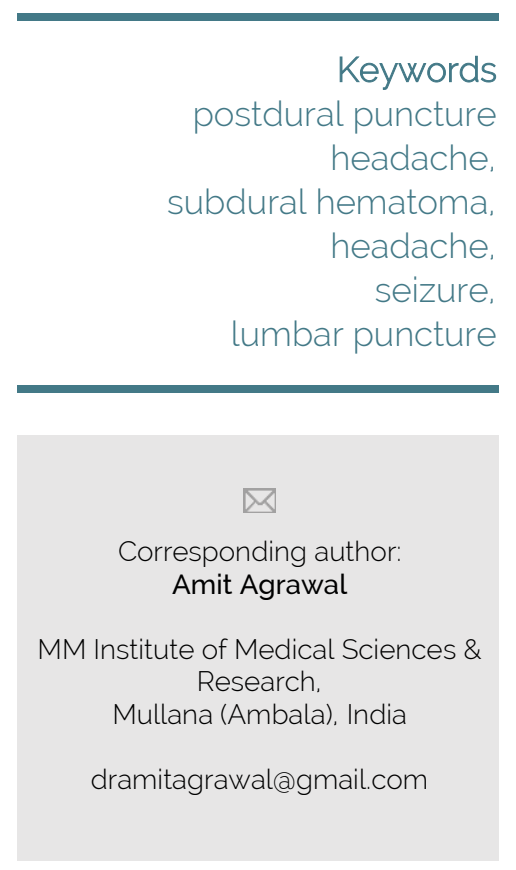

Copyright and usage. This is an Open Access article distributed under the terms of the Creative Commons Attribution Non-Commercial No Derivatives License (https://creativecommons org/licenses/by-nc-nd/4.0/) which permits noncommercial re-use, distribution, and reproduction in any medium, provided the original work is unaltered and is properly cited.

The written permission of the Romanian Society of Neurosurgery must be obtained for commercial re-use or in order to create a derivative work.

ISSN online 2344-4959 (C) Romanian Society of Neurosurgery

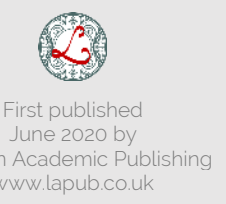


sensorium. Glasgow coma scale was 4. Pupils were bilateral $3 \mathrm{~mm}$ and reacting to light. Plantars were bilateral extensor. There was no history of hypertension or diabetes. There was no history suggestive of bleeding disorders, using tobacco, or alcohol. Complete blood count including platelets and white blood cells and coagulation tests were within normal range. A plain computed tomography (CT) of brain revealed an extensive left frontal temporo- parietal acute SDH with mass effect and midline shift (Figure-1). The patient underwent emergency craniotomy and evacuation of hematoma. He was electively ventilated and could be weaned off from ventilator and recovered well.

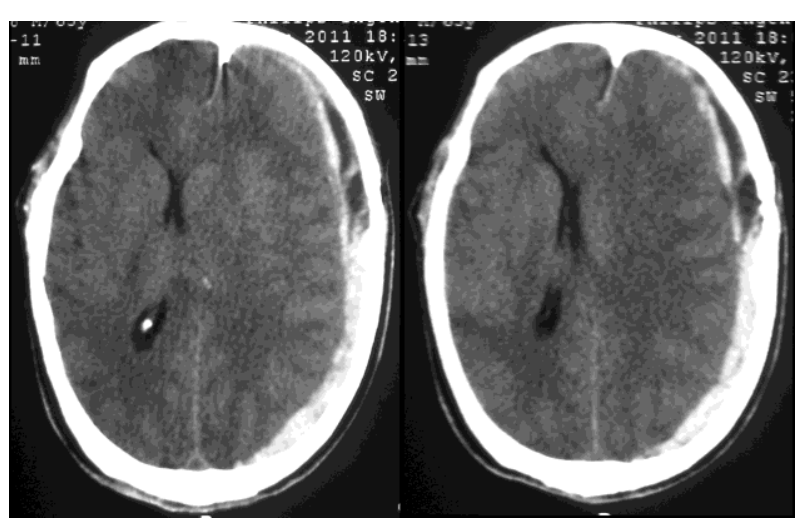

Figure 1. Plain computed tomography scan brain showing large acute left frontal-temporo-parietal subdural hematoma with mass effect and midline shift.

\section{DISCUSSION}

Dural puncture with subsequent postdural puncture headache $(\mathrm{PDPH})$ is a recognized complication of spinal anesthesia. $(13,17)$ The possible mechanism for PDPH is the leakage of cerebrospinal fluid depletes the cushion of CSF supporting the brain and its sensitive meningeal vascular coverings, resulting in gravitational traction on the pain-sensitive intracranial structures causing classical headache. $(2$, 18) Post-dural puncture headache (PDPH) is classically postural and responds within $48 \mathrm{~h}$ to increased fluid intake and bed rest $(5,19,20)$ and more frequently seen in the younger patients and in women. $(4,21,22)$ Severe and prolonged post-dural puncture headache with or without new neurological signs or deficits should be regarded as a warning sign of an intracranial complications (i.e. subdural haematoma or intracerebral haemorrhage). (3, 5-11, $14,15,23-27)$ In contrast to adults, the dura is adherent to skull and may be less stretchable duramater due to either atherosclerosis or agerelated mechanical changes in the epidural space explaining the lower incidence of PDPH. (28) The mechanism responsible for PDPH i.e. the leakage of CSF and subsequent lowering of the intracranial pressure following dural puncture and caudal movement of the spinal cord and brain stretching and tearing dural veins, results in subdural bleeding in the elderly. $(2,5,7,13,18,27,29,30)$ The management of acute SDH depends on size of the hematoma as smaller lesions in conscious patients can be managed conservatively under close supervision, $(5,7,9,31,32)$ however the larger lesions with neurological deficits require neurosurgical intervention and evacuation of hematoma. $(7,8)$ While considering the patient of PDPH for conservative management, particularly a lumbar autologous extradural blood patch as a possible means to stop the CSF leakage one should be cautious and has low threshold for cranial imaging as the procedure can worsen the patient and neurological deterioration if there is intracranial hematoma. (7)

\section{CONCLUSION}

In summary, prolonged and persistent post dural puncture headache complicated by atypical neurological deterioration following spinal anesthesia should prompt the physician to consider the possibility of intracranial complications and to seek immediate radiological investigations to avoid a potential negative outcome.

\section{REFERENCES}

1. Evans RW, Armon C, Frohman EM, Goodin DS. Assessment: Prevention of postâ€'lumbar puncture headaches. Neurology. 2000;55(7):909-14.

2. Ahmed S, Jayawarna C, Jude E. Post lumbar puncture headache: diagnosis and management. Postgraduate medical journal. 2006;82(973):713.

3. Kim HJ, Cho YJ, Cho JY, Lee DH, Hong KS. Acute subdural hematoma following spinal cerebrospinal fluid drainage in a patient with freezing of gait. Journal of Clinical Neurology (Seoul, Korea). 2009;5(2):95.

4. Kuntz K, Stevens J, Offord K, Ho M. Postâ€[lumbar puncture headaches. Neurology. 1992;42(10):1884-.

5. Acharya R, Chhabra S, Ratra M, Sehgal A. Cranial subdural haematoma after spinal anaesthesia. British journal of anaesthesia. 2001;86(6):893. 
6. Macon ME, Armstrong L, Brown E. Subdural hematoma following spinal anesthesia. Obstetric Anesthesia Digest. 1990;10(2):108.

7. Verda M, MartÃ-nez-Lage J, Alonso B, SÃjnchez-Ortega J, Garcia-Candel A. Non-surgical management of intracranial subdural hematoma complicating spinal anesthesia Manejo no quirÃ ${ }^{\circ}$ rgico de hematoma subdural intracraneal tras anestesia espinal complicada. NeurocirugÃ-a. 2007;18(1).

8. Pavlin DJ, McDonald JS, Child B, Rusch V. Acute subdural hematoma-an unusual sequela to lumbar puncture. Anesthesiology. 1979;51(4):338.

9. Mantia AM. Clinical report of the occurrence of an intracerebral hemorrhage following post-lumbar puncture headache. Anesthesiology. 1981;55(6):684.

10. Duarte $W L$, Geber DG. Hematoma Subdural ap $\tilde{A}^{3} S$ PunÃßÃ£o Inadvertida da Dura-MÃ iter. Relato de Caso. Revista Brasileira de Anestesiologia. 2008;58(4):387-90.

11. Chiravuri S, Wasserman R, Chawla A, Haider N. Subdural hematoma following spinal cord stimulator implant. Pain physician. 2008;11(1):97-101.

12. Lee ACW, Lau Y, Li CH, Wong YC, Chiang AKS. Intraspinal and intracranial hemorrhage after lumbar puncture. Pediatric Blood \& Cancer. 2007;48(2):233-7.

13. Cantais E, Behnamou D, Petit D, Palmier B. Acute Subdural Hematoma following Spinal Anesthesia with a Very Small Spinal Needle. Anesthesiology. 2000;93(5):1354-5.

14. Komplikasyonu EA, Hematom S. Intracranial Chronic Subdural Haematoma as a Complication of Epidural Anesthesia. Turkish Neurosurgery. 2009;19(3):285-7.

15. Suess $O$, Stendel R, Baur S, Schilling A, Brock $M$. Intracranial haemorrhage following lumbar myelography: case report and review of the literature. Neuroradiology. 2000;42(3):211-4.

16. Newrick P, Read D. Subdural haematoma as a complication of spinal anaesthetic. British Medical Journal (Clinical research ed). 1982;285(6347):1047-8.

17. Berger CW, Crosby ET, Grodecki W. North American survey of the management of durai puncture occurring during labour epidural analgesia. Canadian Journal of Anesthesia/Journal canadien d'anesthÃ@sie. 1998;45(2):110-4.

18. Hatfalvi Bl. Postulated Mechanisms for Postdural Puncture Headache and Review of Laboratory Models: Clinical Experience. Regional Anesthesia and Pain Medicine. 1995;20(4):329.

19. Nolte C, Lehmann TN. Postpartum headache resulting from bilateral chronic subdural hematoma after dural puncture. American Journal of Emergency Medicine, The. 2004;22(3):241-2.

20. Skoldefors $\mathrm{E}$, Olofsson $\mathrm{Cl}$. Intracranial subdural haematoma complicates accidental dural tap during labour. European Journal of Obstetrics and Gynecology and Reproductive Biology. 1998;81(1):119-21.

21. Bridenbaugh PO, Greene NM, Brull SJ. Spinal (subarachnoid) neural blockade. Neural blockade in clinical anaesthesia and management of pain 3rd Edition Philadelphia: Lippincott-Raven. 1998:203-42.

22. Leibold RA, Yealy DM, Coppola M, Cantees KK. Post-duralpuncture headache: characteristics, management, and prevention. Annals of emergency medicine. 1993;22(12):1863-70.

23. Stocks G, Wooller D, Young J, Fernando R. Postpartum headache after epidural blood patch: investigation and diagnosis. British journal of anaesthesia. 2000;84(3):407.

24. Vaughan D, Stirrup C, Robinson P. Cranial subdural haematoma associated with dural puncture in labour. British journal of anaesthesia. 2000;84(4):518.

25. Kayacan N, ArÄ $\pm c \ddot{A} \pm$ G, Karsl $\ddot{A} \pm B$, Erman M. Acute subdural haematoma after accidental dural puncture during epidural anaesthesia. International journal of obstetric anesthesia. 2004;13(1):47-9.

26. Ozdemir O, Calisaneller T, Yildirim E, Caner H, Altinors N. Acute spontaneous spinal subdural hematoma in a patient with bilateral incarcerated inguinal hernia. Joint Bone Spine. 2008 May;75(3):345-7.

27. Hung C, Tan S. Acute-on-chronic subdural haematoma, a rare complication after spinal anaesthesia. Hong Kong Med J. 2003;9(5):384-6.

28. Vandam LD, Dripps RD. Long-term follow-up of patients who received 10,098 spinal anesthetics. Journal of the American Medical Association. 1956;161(7):586.

29. Thors $\tilde{A} \odot \mathrm{n}$ G. Neurological Complications After Spinal Anaesthesia: And Results from 2493 Follow-up Cases: Kungl. Boktrykeriet PA Norstedt \& Soner; 1947.

30. Lee K. The pathogenesis and clinical significance of traumatic subdural hygroma. Brain injury. 1998;12(7):595-603.

31. Scavone BM, Wong CA, Sullivan JT, Yaghmour E, Sherwani SS, McCarthy RJ. Efficacy of a prophylactic epidural blood patch in preventing post dural puncture headache in parturients after inadvertent dural puncture. Anesthesiology. 2004;101(6):1422.

32. 32. Blake D, Donnan $G$, Jensen $D$. Intracranial subdural haematoma after spinal anaesthesia. Anaesthesia and intensive care. 1987;15(3):341-2. 